\title{
大夕張地区における森林鉄道橋梁の特徵と評価に関する研究*
}

\section{A Report of Forest Railway Bridges at Ouh-Yuubai District in Hokkaido}

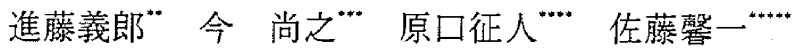
by Yoshiro SHINDO, Naoyuki KON, Masato HARAGUCHI, Keiichi SATOH

\begin{abstract}
北海道夕張市大夕張地区は, 第二次世界大戦前の帝室林野局時代から森林鉄道による運材が積極 的に取り組まれた地域である。この地区では木造橋の落橋事故の多発から北海道内の森林鉄道とし ても戦後早い時期から積極的に鉄橋が導入されたほか，昭和30年代初頭の大夕張ダム建設による森 林鉄道補償工事にともない三弦トラス橋梁, 重構析鉄道橋など極めて特徵的な構造様式の橋梁が多 く架橋された，本研究は森林鉄道廃止後も現存するそれらの橋梁について，所在や建設経緯を明ら かにし，技術的特徴を報告するものである。
\end{abstract}

1.はじめに

北海道の拓殖に森林資源開発が果たしてきた役割 には極めて大きなものがある。しかしながら寒冷な 気候に加え消費地から遠距離にあるなど，その輸送 の確保は常に大きな問題であった。

産業鉄道の一類型として位置付けられる森林鉄道 (軌道) が，北海道において導入されたのは1908 （明治41）年である。この年，王子製紙苫小牧工場 専用鉄道（苫小牧一支䇗湖畔, 総延長 $27.9 \mathrm{Km}$ ），三 井物産専用鉄道（苫小牧一鵡川，棇延長 $28.5 \mathrm{~km}$ ）の 両鉄道が開通した。以来, 1968（昭和43）年の定山 渓森林鉄道（林野庁所管）の廃止に至るまで，森林 鉄道（軌道）は北海道の森林開発における主要な運 材機関として，道南地区を除く北海道の全域におい て利用され，北海道林業の発展に多大な貢献をした と評価されている。この北海道の森林鉄道（軌道） に関する研究は，既に先達によって取り組みがなさ れており，特に林業機械化の史実を記録する観点か

\footnotetext{
* Keywords; 森林鉄道橋梁，重構桁鉄道橋，三弦卜 ラス橋梁

**フェロー 北海道開発コンサルタント

干004-8585 札幌市厚別区厚別中央 1 条 5丁

** 正会員北海道教育大学教育学部旭川校

*** 正会員北海道大学大学院工学研究科研究生

**** フェロー 北海道大学大学院工学研究科 e-Mail:ys $112 \mathrm{emb}$. docon
}

進藤義郎 : 大夕張地区における森林鉄道檽梁の特徴之評価に関する研究

ら，森林鉄道（軌道）に供用された車両に関する緻 密かつ詳細な研究がなされている。

しかしながら，森林鉄道において用いられた橋梁 など土木構造物に関する報告や体系だった研究の数 は極めて少ない現状がある．森林鉄道（軌道）は産 業鉄道の一類型であり, 人里離れた山奥において展 開されると同時に，営林事業の展開に合わせてダイ ナミックに改廃を繰り返したことから，人の目に触 れる期間も短く多くの関心を呼ばなかったことも原 因の一つであろう。しかし，厳しい制約条件の下， 技術的に工夫のなされた橋梁が数多く建設されてお り，それらの史実をしっかりと記録することは橋梁 技術史において意味あるものと考えられる。

夕張市の南部から鹿島にかけてのシューパロ湖周 辺地域（大夕張地区）では，木造橋の落橋事故の多 発から北海道内の森林鉄道としても戦後早い時期か ら積極的に鉄橋が導入されるなど技術的な特徴が見 られる地域である。また，昭和30年代初頭の大夕張 ダム建設による森林鉄道補償工事にともない三弦卜 ラス形式橋梁, 重構桁鉄道橋など極めて特徵的な構 造様式の橋梁が多く架橋された地域でもあり，北海 道の橋梁技術史を考えるうえで貴重な現物資料が多 数残存している.

しかし，同地域は夕張シューパロダムの建設によ り水没することとなっている。このため将来に向け 
て記録を残し，必要なものは後世に伝えるべき現物 の土木遺産として，移設保存や活用が望まれる。

本研究では以上より，北海道の森林鉄道に関する 土木遺産が豊富に残る同地域における森林鉄道橋梁 の建設経緯や所在，諸元などについて整理し，その 特徵について報告するものである。

\section{2. 大夕張地区での森林鉄道建設の展開と特徴 ${ }^{1}$}

大夕張地区における森林鉄道建設は，昭和10年代 に入り御料林の木枋搬出のため主夕張森林鉄道 （1937年竣工）が建設されことに始まる。そ後， 第二次世界大戦中であったが建設が進み，下夕張森 林鉄道（1945年竣工）・張看森林鉄道（1946年竣 工）がそれぞれ供用されるに至った。さらに，林政 統一後も営林事業地の奥地化などにより䐓次延長さ れた。これら森林鉄道によって運ばれた木材は運炭 用の三菱大夕張鉄道によって国鉄清水沢駅まで運ば れ，さらに各地へと運ばれた。
また，昭和30年代には夕張川を堰止めた大夕張ダ 厶が建設され（1959年完成），運炭鉄道と森林鉄道 の移転補償が行われた，特に森林鉄道は総延長約 $10 \mathrm{~km}$ の補償工事となり，深く入り組んだ沢を横断す るために多くの橋梁が架けられることとなった。こ のためできるだけ架橋費用を抑えるために既存橋梁 の転用を行い，橋梁延長 $381.8 \mathrm{~m}$ の三弦トラス構造の 橋梁が架橋されるに至った（1958年供用開始）。こ の時期は，森林鉄道が木材資源開発の基幹インフラ として重要な位置を占めていた時期といえよう。

しかしながら，昭和 30 年代前半から森林鉄道が 次々と廃止され1966年にはすべて廃止となった。こ の背景には林道開発によるトラック運材への切り替 わりと同時に，1954（昭和29）年の15号台風（洞爺 丸台風）による風倒木処理に森林鉄道システムが十 分対応できなかったこともある。また石炭輸送を 行ってきた三菱大夕張鉄道も1973年に南大夕張一大 夕張炭山間が廃止となり，1987年には残る清水沢一 南大夕張間方廃止された。

表 1 夕張シューパロ湖周辺地域における鉄道建設の推移（作成：進藤拲郎）

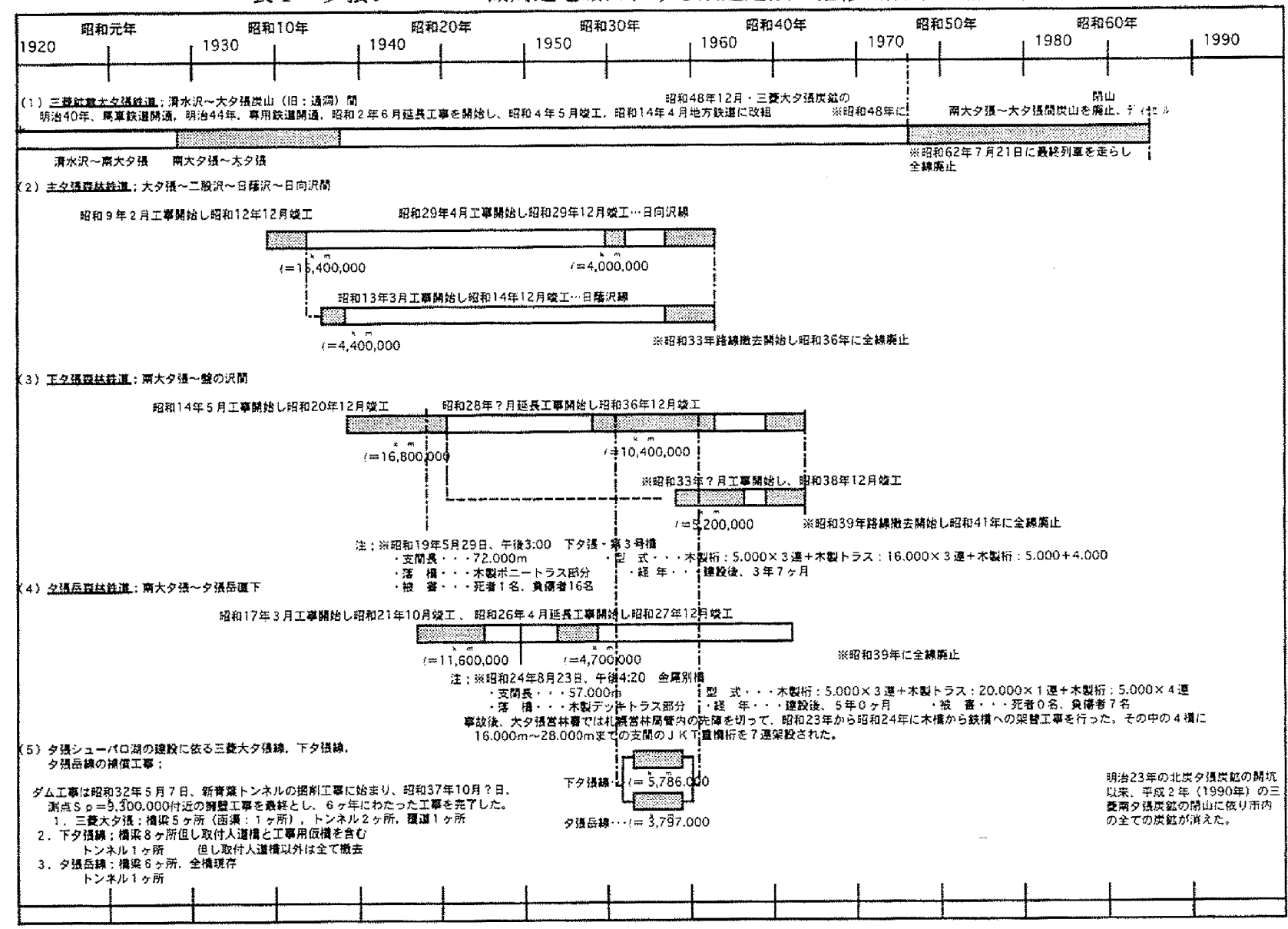


表 1 にこれら鉄道建設の展開と推移を示 すまたた図1は各鉄道の所在を示したもので ある。

このように狭いエリアに運炭鉄道と森林鉄 道が集中していること，建設期間が長期にわ たっていること, 遺構が比較的数多く残って いることなどが大夕張地区の特徴である，石 炭や木材の搬出という産業鉄道での構造物に ついては，その所在や諎元についてあまり明 らかになって㧈らず，系譜やその供用につい ても不明な点が多い，本地区は産業用土木構 造物の歴史的発展を知る上で貴重な存在とい えよう。

\section{3. 大夕張地区に残存する森林鉄道橋梁の 実際と特徵 1}

\section{（1）供用された森林鉄道橋梁の一覧}

供用された構造物の特徵や現状を全体的に みると，(1)山間部のため，沢を横断する小橋 梁が多い. (2)森林鉄道では除却された橋梁も 多い，その一方で残置され結果として転倒したと思 われる橋梁なども残存していることがわかる。また 各路線別の構造物の特徴を表 2 に示す。

\section{（2）供用された橋梁の現状}

\section{(1) 主夕張森林鉄道}

三菱石炭鉱業の運炭鉄道（三菱大夕張鉄道：廃 止）終点であった大夕張炭山から，夕張川本流に沿 い上流へ敷設されていた主夕張森林鉄道では，7橋 梁が架設された，現在，倒壊するなど完全な姿で現 存するものはない.

夕張本流第二号橋梁は橋朋, 橋台ともに解体撤去 されたが，残り6 橋梁については橋脚や橋台が残存 している。また，橋脚についても倒壊して現存して いるほか，倒壊により橋げたが下流側に残るなど痛 ましい姿をさらしている，周辺は蛇紋岩質の急峻な 地形であり雨量も多いことから，今後現存する橋脚

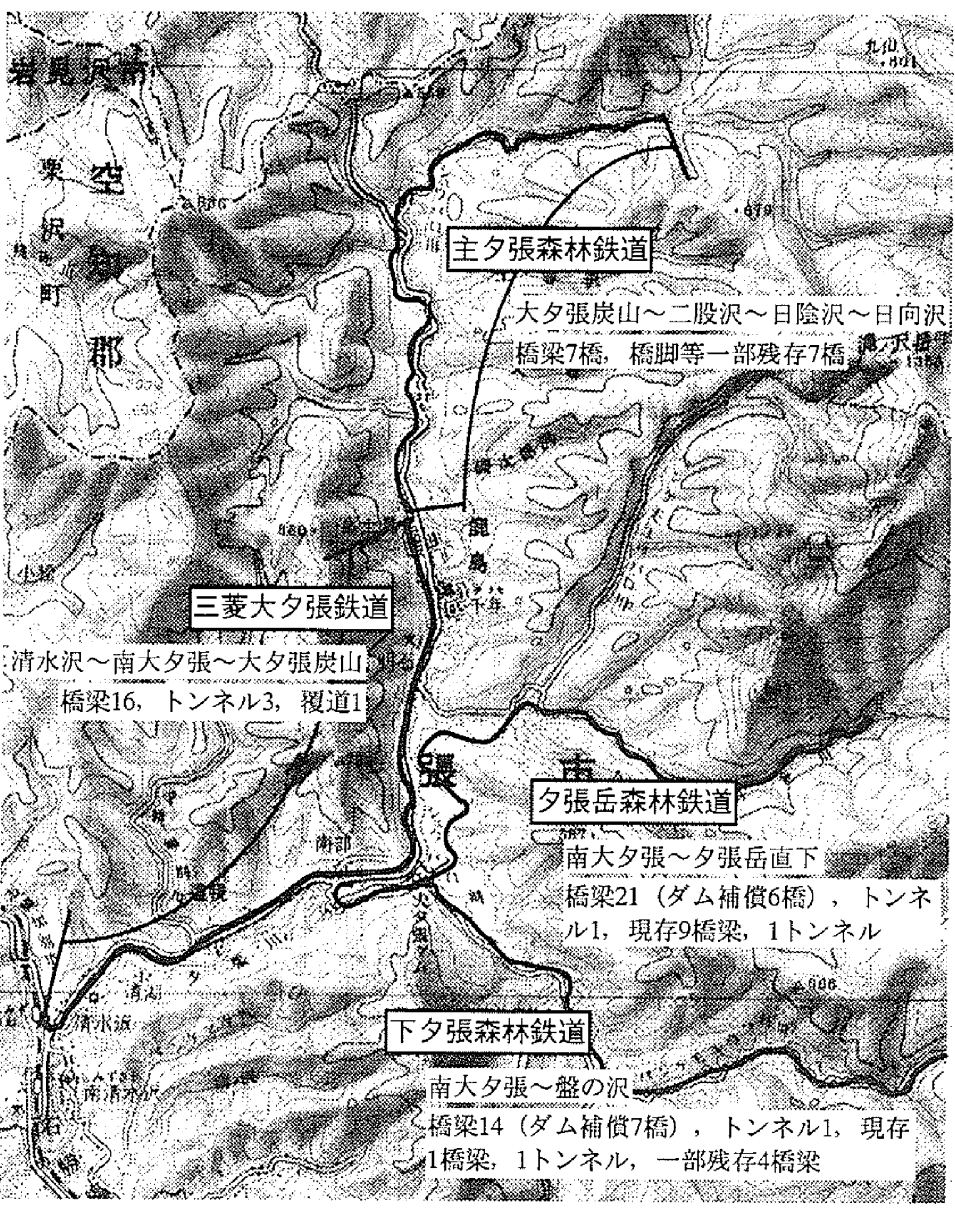

図 1 大夕張地区における森林鉄道などの所在

（国土地理院20万分の一地势図「夕張」に加筆，作成：今 尚之）

なども倒壊の危険性を持つと考えられる。

\section{(2) 下夕張岳森林鉄道}

大夕張ダム下流の南部地区（南大夕張）を起点と した下夕張岳森林鉄道は，昭和 20 年後半から 30 年代 前半にかけての大夕張ダム建設時に構造物は撤去さ れ，ダム建設の補償工事として新たに架け替えされ た。しかし，森林鉄道廃止後，夕張川を渡る第一号 橋が撤去されたほか，現存する橋梁のほとんどが上 部構造が撤去されており完全な姿で残るものは，軌 条と木床板の組み合わせ形式による下夕張取り付け 人道橋のみである。しかし現存する橋台のなかには 土留め機能に特徵的なものも残っている.

\section{(3) 夕張岳森林鉄道}

大夕張ダムサイト近傍にて下夕張岳森林鉄道と分 岐する夕張岳森林鉄道もまた，大夕張ダム建設時に 既存の構造物は撤去された。しかし；多么建設の補 償工事に伴い特徵的な橋梁構造物が多数架橋され た.これらの橋梁には三弦トラス橋や重構桁鉄道橋 
表 2 大夕張地区に㧍ける森林鉄道橋の概要（作成：潐藤堷郎）

主夕張森林鉄道：大夕張宸山（日名一通洞）二二股沢～日险沢～日向㳊間

\begin{tabular}{|c|c|c|c|c|}
\hline 撕橾物名称 & 延長 $(\mathrm{m})$ & 掅造形式 & 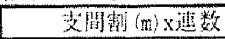 & 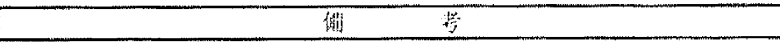 \\
\hline 多張川本流 1 号櫈 & & 不 明 & 不明 & 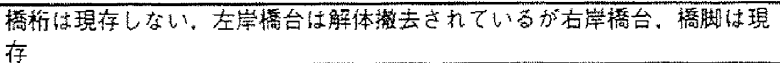 \\
\hline 夕張川爽流 2 号橋 & & 不 明 & 不 明 & 完全に解体做去 \\
\hline 烈电沢橲 & 18 & 銅裂銀售 & $9 m \times 2$ & 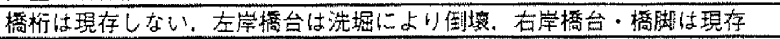 \\
\hline 客称：不閒 & 40 & 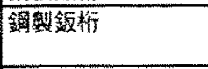 & $10 m \times 4$ & 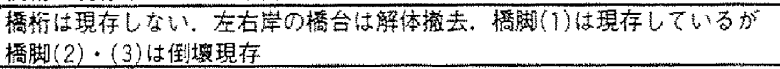 \\
\hline 名称：不明 & 31 & 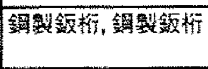 & $9 \mathrm{~m} \times 2,13 \mathrm{~m} \times 1$ & 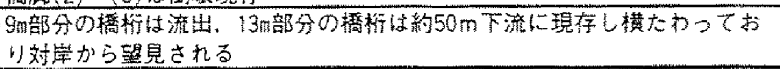 \\
\hline 苦称：不明 & 40 & 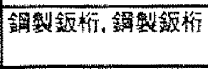 & $9 \mathrm{~m} \times 3,13 \mathrm{~m} \times 1$ & 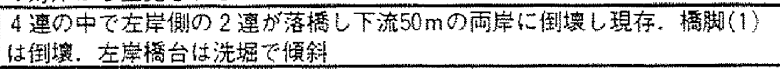 \\
\hline 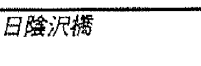 & 60 & 銅製鈑樎 & $15 \mathrm{~m} \times 4$ & 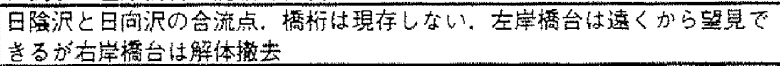 \\
\hline
\end{tabular}

\begin{tabular}{|c|c|c|c|c|}
\hline 棈造物名称 & 延長 $(m)$ & 搆造形式 & 支間割 $(m) \times$ 連数 & 備考 \\
\hline 下夕張川棰 & 89.00 & 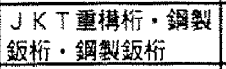 & $27.5 \mathrm{~m} \times 2,20 \mathrm{~m} \times 1,14 \mathrm{~m} \times 1$ & 下夕張川の本流に架設された，新設第6 号橎に転用されたと考えられる。 \\
\hline 第1㤐橋 & 52.00 & 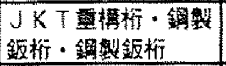 & $20 \mathrm{~m} \times 1,16 \mathrm{~m} \times 1,16 \mathrm{mx} 1$ & 昭和34年（1959年）解体撴去 \\
\hline 第2号檑 & $?$ & & & 解体做去，瓷料不明 \\
\hline 第3号槚 & $?$ & & & 解体撚去，澬料不明 \\
\hline 第 4 号橝 & 29.08 & 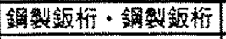 & $6 m \times 1,11.54 m \times 2$ & 解体撴去 \\
\hline 第11总栈橋 & 15.45 & 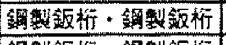 & $6 \mathrm{~m} \times 2,3.45 \mathrm{~m} \times 1$ & 鲜体搭去 \\
\hline 第14亘栈撢 & 17.54 & 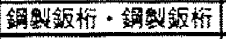 & $6 \mathrm{~m} \times 1,11,54 \mathrm{~m} \times 2$ & 解体潄去 \\
\hline 多張岳トンネル & 120.00 & & & 必么捕償建設 \\
\hline 第 1 号楿(東京鉄骨kk) & 381.80 & \begin{tabular}{|l|} 
三弦卜ラス・弦卜 \\
ラス・弦トラス
\end{tabular} & $39 \mathrm{~m} \times 1,77 \mathrm{~m} \times 1, \quad 52 \mathrm{~m} \times 5$ & 多么補集架設 \\
\hline 第 2 号標(桜曲機榑kk) & 62.50 & 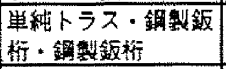 & $45 \mathrm{~m} \times 1,6 \mathrm{~m} \times 1,10 \mathrm{~m} \times 1$ & 名么神傅架架設 \\
\hline 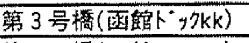 & 20.60 & 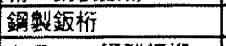 & $20 \mathrm{~m} \times 1$ & 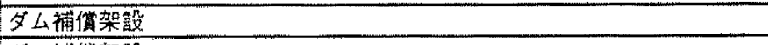 \\
\hline 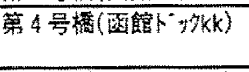 & 81.35 & 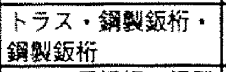 & $60 \mathrm{mx1}, 9.85 \mathrm{mxl}, 10 \mathrm{mx} 1$ & ダム辅㶈架設 \\
\hline 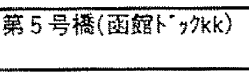 & 37.56 & 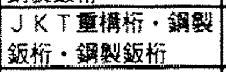 & $20 \mathrm{~m} \times 1,6 \mathrm{~m} \times 1,10.155 \mathrm{~m} \times 1$ & 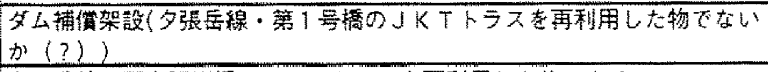 \\
\hline 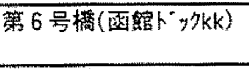 & 102.35 & 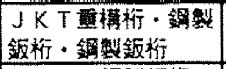 & $27.5 \mathrm{~m} \times 2,14 \mathrm{~m} \times 1,15.5 \mathrm{~m} \times 2$ & 夕張岳線・下夕張川檑の」K K Tトラスを再利用した物である。 \\
\hline 金尾別楿 & 72.00 & 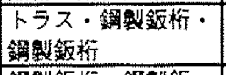 & $26 \mathrm{~m} \times 2,10 \mathrm{~m} \times 1,10 \mathrm{~m} \times 1$ & 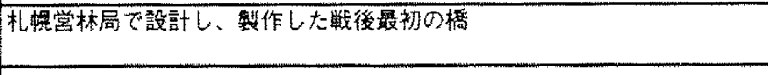 \\
\hline 白金沢 第 1号槚 & 45.08 & 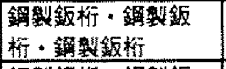 & $11.54 \mathrm{~m} \times 2,6 \mathrm{~m} \times 3,4 \mathrm{~m} \times 1$ & \\
\hline 白金沢 第 2号褔 & 39.54 & 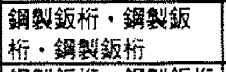 & $11.54 \mathrm{~m} \times 1,10 \mathrm{~m} \times 1,6 \mathrm{~m} \times 3$ & \\
\hline 白金沢 第 3量橋 & 29.58 & 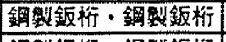 & $10 \mathrm{~m} \times 2,9.58 \mathrm{~m} \times 1$ & \\
\hline 白金沢 第 4号露 & 42.76 & 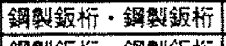 & $12.76 \mathrm{~m} \times 1,10 \mathrm{~m} \times 3$ & \\
\hline 画金沢 第 5 号橋 & 32.00 & 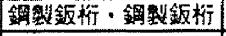 & $10 \mathrm{~m} \times 2,6 \mathrm{~m} \times 2$ & \\
\hline 白金沢 第 6 受啝 & 40.00 & 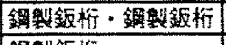 & $15 m \times 2,10 m \times 1$ & 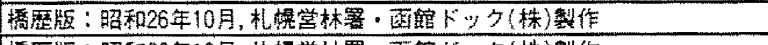 \\
\hline 白金沢 第7号檫 & 45.00 & 龬算鈑桁 & $115 \mathrm{~m} \times 3$ & 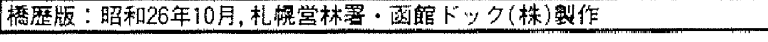 \\
\hline
\end{tabular}

下夕張㷊林鉄道 : 南大夕張 盤の沢間

\begin{tabular}{|c|c|c|c|c|}
\hline 椪造物名称 & 延長灰と & 構造形式 & 支閐割( & 满考 \\
\hline 多張川㳊 & & 不 明 & 不 明 & 一時、步道橋として再利用されていたが、その後、解体塩去 \\
\hline 第1咢㨨 & 78.00 & 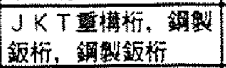 & $20 \mathrm{~m} \times 2,10 \mathrm{~m} \times 2,9 \mathrm{~m} \times 2$ & 多張シューバ口湖の工事に伴い 昭和34年(1959年)に解体整去 \\
\hline 第2㞻虂 & 62.00 & 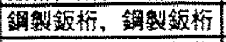 & $14 \mathrm{~m} \times 4,6 \mathrm{~m} \times 1$ & 头么锤設時に解体徹去 \\
\hline 第3号播 & 62.00 & 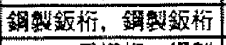 & $14 m \times 4,6 m \times 1$ & 多么建設時に解体整去 \\
\hline 芽 4 号符 & 44.00 & 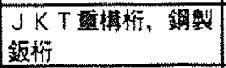 & $14 m \times 2,6 m \times 2$ & 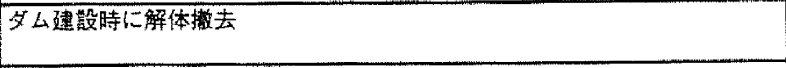 \\
\hline プトーサルシナイ檑 & 10.00 & 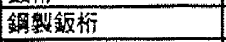 & $10 \mathrm{~m} \times 1$ & 父么建㔀封に解体敏去 \\
\hline 下多張トンネル & 420.00 & & & 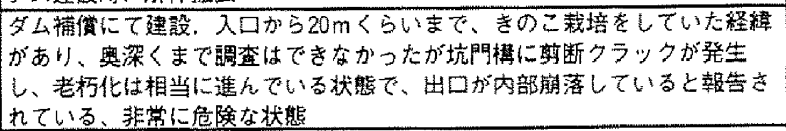 \\
\hline 第1号橋 & 14.03 & 3绎問連繶，トラス & $23 m \times 382$ & 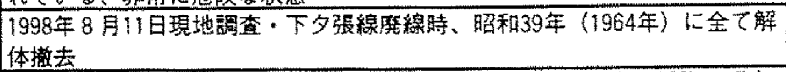 \\
\hline 第 2 号整 & 44.42 & 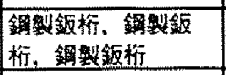 & $20 \mathrm{~m} \times 1,9.47 \mathrm{~m} \times 1,14 \mathrm{~m} \times 1$ & 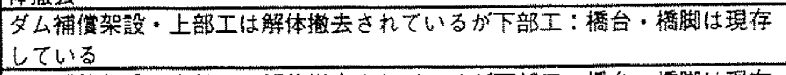 \\
\hline 第 3 号榙 & 36.80 & トラス & $36 \mathrm{~m} \times 1$ & 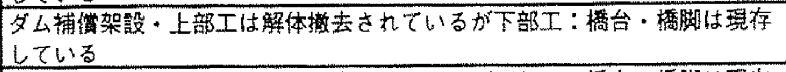 \\
\hline 第 4 号標 & 57.64 & 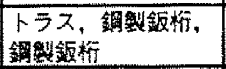 & $40 \mathrm{mx}=8.322 \mathrm{mx} 1,9.815 \mathrm{mx}$ & 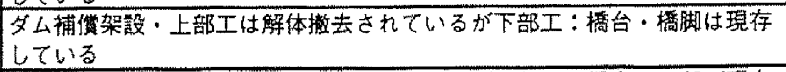 \\
\hline 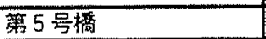 & 55.80 & $1-7 x$ & $55 \mathrm{~m} \times 1$ & 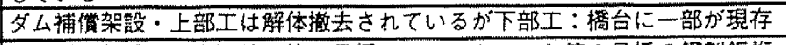 \\
\hline 第6号槚 & 49.30 & 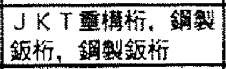 & $20 \mathrm{~m} \times 1,14 \mathrm{~m} \times 1,14 \mathrm{~m} \times 1$ & 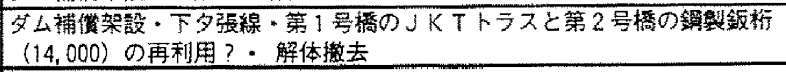 \\
\hline 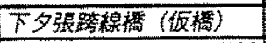 & 10.50 & 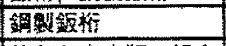 & $10 \mathrm{~m} \times 1$ & 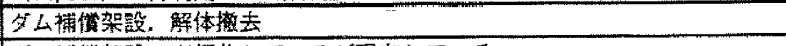 \\
\hline 下夕張線取り付け人道橋 & 99.40 & 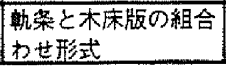 & $7 \mathrm{7m \times 14}$ & タム㭪償架設・老朽化しているが現存している。 \\
\hline
\end{tabular}




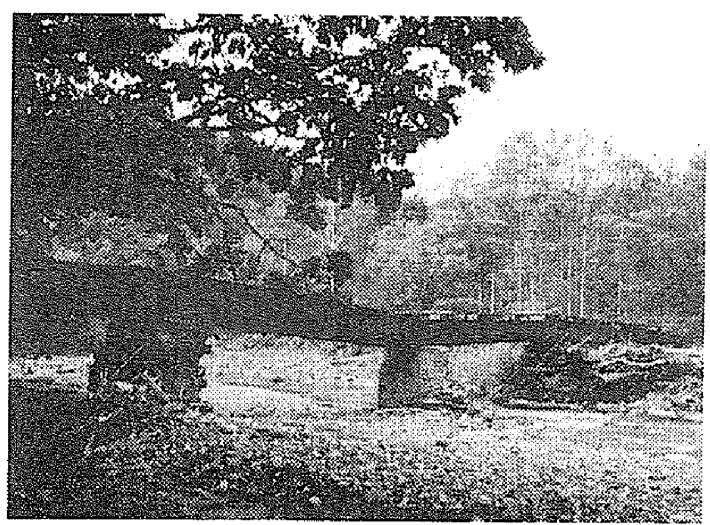

写真 1 白金沢第 4 橋梁（撮影: 西野昭平）

など極めて特徵的な橋梁が含まれている。さらに上 流にも鋼製版桁が残存している（写真 1 ）。このよ 橋梁の多くが除却された中，貴重な現物資料を提供 しているほか，札幌林友など当時の営林事業を記録 する資料も残っている。

\section{4. 大夕張地区における森林鉄道橋梁の特徴と} しての鋼橋の導入と木橋落橋事故 ${ }^{2>31}$

\section{（1）木橋の使用と鋼橋の導入}

北海道内の森林鉄道では木橋の利用が一般的で あった。例えば，芦別営林署内の金山森林鉄道には 中央支間 $36 \mathrm{~m}$ の大スパン橋が架設され，足寄森林鉄 道では全長 $200 \mathrm{~m}$ のトラス橋が架橋されている。こ れらの長大橋の事例が示すところから，北海道内の 森林鉄道では木橋の架橋技術やその維持技術も保有 していたとも考えられる。しかし，定山渓森林鉄道 では架設後4年の $30 \mathrm{~m}$ 木造デッキトラスが積雪荷重に うに現物で残る橋梁が数多く，北海道内の森林鉄道

より崩落した事故が発生（1946（昭和21）年5月13 日）したほか，橋梁の耐久性が5８年の短寿命であ ることなど，安全性や耐久性の問題から，1948年度 から1954年度までに札幌営林局管内で38ヶ所, 棇延 長 $1,510.99 \mathrm{~m}$ の規模で鋼橋への置き換えや新設が進め られた。このうち大夕張地区だけで 21 所, 総延長 $756.69 \mathrm{~m}$ と実に全体の $50 \%$ を占めるに至っている。 さらに，1948年度～1951年度にかけて鋼橋に置き換 えまたは新設が行われたのは大夕張営林署管内のみ であるなど，大夕張地区では積極区的に鋼橋の利用 がなされたと言えよう。

\section{（2）大夕張地区における落橋事故と鋼橋の導入}

大夕張地区では，1944（昭和19）年と1949年に落 橋事故（表2）が続き，死者も出るなど重大事故が 発生した。その原因の一つに大夕張で産出する木材 の強度が関係していることがわかり，よりいっそう 積極的に鋼橋の置き換えと使用が進められた。大 張営林署では1948（昭和23）年から翌1949年にかけ て, $16 \mathrm{~m}$ から $28 \mathrm{~m}$ 支間の重構椼鉄道橋が合計7連架設 されている。

戦後まもない時期であり，さらに，産業用鉄道で あるためにコストをできるだけ低減するという厳し い制約条件のものとでの鋼橋の整備であったことか ら，旧国鉄からの払い下げ橋林再利用や重構桁鉄 道橋の導入など特徵的な架橋がなされたものと思わ れる。

\section{（3）金尾別橋梁の事故原因と橋梁の新設}

表 3 大夕張地区における森林鉄道木橋落橋事故と新設橋梁 (作成: 今 尚之)

\begin{tabular}{|c|c|c|c|c|}
\hline 路線·橋名 & 福長，構造等 & 事故年月日 & 事故内容 & 新設橋 \\
\hline $\begin{array}{l}\text { 下夕張森林鉄道 } \\
\text { 第 } 3 \text { 号橋梁 }\end{array}$ & $\begin{array}{l}\text { 橖長 } 72 \mathrm{~m}, \text { 木造ポ } \\
\text { ニートラス } \\
(16 \mathrm{~m} \times 3), \text { 木造版 } \\
\text { 桁 }(5 \mathrm{~m} \times 4,4 \mathrm{~m} \times \\
1)\end{array}$ & 1944年5月29日 & 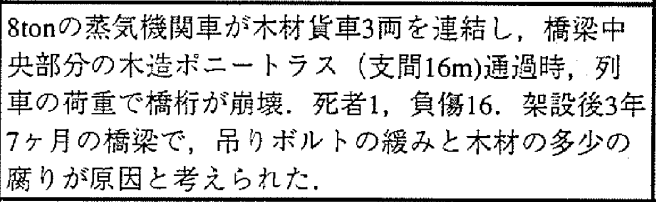 & $\begin{array}{l}\text { 橋長 } 62 \mathrm{~m}, \text { 鎆製版桁 } \\
(14 \mathrm{~m} \times 4+6 \mathrm{~m} \times 1) ， 1950 \\
(\text { 昭和 } 25) \text { 年架設 }\end{array}$ \\
\hline $\begin{array}{l}\text { 夕張岳森林鉄道 } \\
\text { 金尾別橋梁 }\end{array}$ & $\begin{array}{l}\text { 橋長 } 57 \mathrm{~m}, \text { 木造 } \\
\text { デッキトラス } \\
(20 \mathrm{~m} \times 1), \text { 木造 } \\
\text { 版桁 }(5 \mathrm{~m} \times 7)\end{array}$ & 1949年8月23日 & 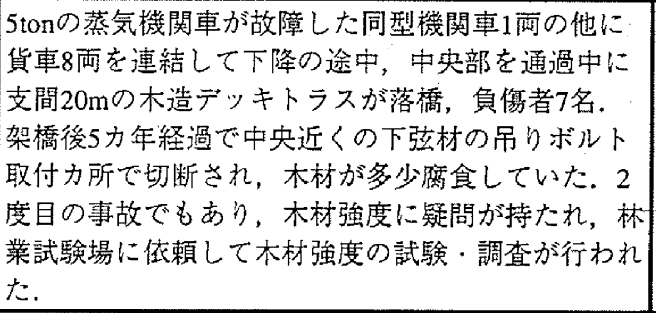 & 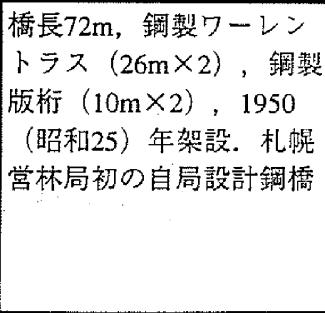 \\
\hline
\end{tabular}


二度目の事故となった金尾別橋梁の落橋後，林業 試験場にその原因調査が依頼された。その結果，

（i）大夕張産の木材は简朽の程度が他地区のものよ りも程度が大きい。しかし実験室内の耐久試験では 腐朽に対する抵抗が少ないという結果は得られな かった（ii）成長の良すぎる材を使用しており， ボルト接合部にやや節の侵入が多い。（iii）トラス 橋のキャンバー整正のため，吊りボルト締め上げに 際し，著しい緊締を行い行材を損った可能性があ
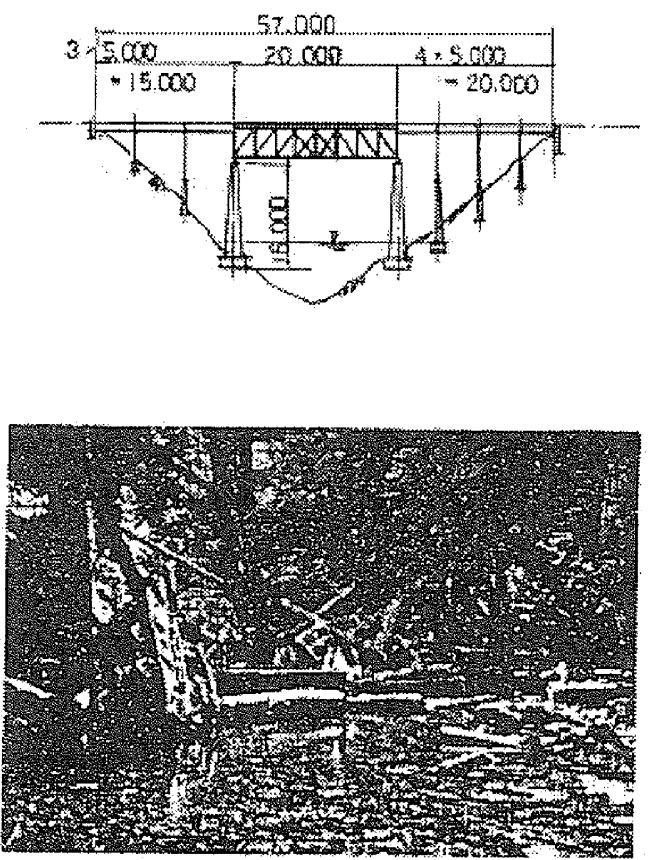

図 2 旧金尾別橋梁の一般図と落橋の様子 (一般図作成 : 進藤義郎, 写真 : 札幌林友第 1 号)
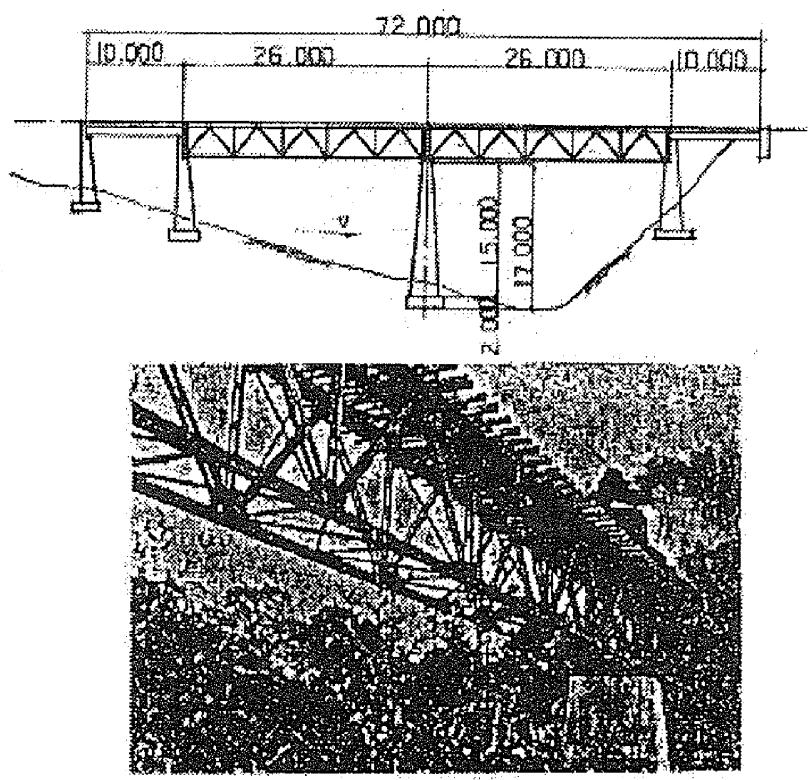

図 3 新金尾別橋梁の一般図と写真 （一般図作成：進藤義郎，写真札幌林友第 1 号）
る。ことなどが明らかとされ，その後の木橋の維 持，管理に抢いて参考とされた。さらにっこれらの 結果を受けて，札幌営林局（当時）初の自局設計に よる鋼橋として金尾別橋梁が新設された。

\section{5.夕張岳線に残る大夕張ダム建設補償橋梁}

（1）大夕張ダム建設に伴う森林鉄道補償工事と特 徵的な橋梁"

1952（昭和27）年より，夕張川下流部の農業潅溉 用水の確保と発電をその主な目的とした利水専用多 目的ダムである，大夕張ダムの建設調査が始まり， ダムによる堰止湖（シューパロ湖）によって森林鉄 道下夕張線と夕張岳線の一部が水没することとなっ た。このため，北海道開発局では延べ延長 $9,583 \mathrm{~m}$ およぶ森林鉄道の移設補償工事が行い，建設部道路 課が担当した。補償工事は1953－1958年の間に行わ れあらたに，隧道 2 ヶ所の掘削と，12ヶ所の橋梁 が架橋された，特に夕張岳線においては夕゙ム直上流 でシューパロ湖を横断するため, 全長 $381.80 \mathrm{~m} の 三$ 弦構造のトラス橋が架橋されることとなった。ま た，重構垳鉄道橋など特徵的な構造の橋梁が架橋さ れた。なお夕張岳森林鉄道は1963年に廃止され，そ の後現在まで未供用のまま現存している。図 4 に大 夕張ダム補償工事で架橋された，夕張岳森林鉄道の 各橋梁の所在を示す。

\section{（2）三弦トラス構造を採用した夕張岳森林鉄道夕} 張岳第 1 号橋梁 ${ }^{4}$

(1) 夕張岳第 1 号橋梁の諸元と概要

第 1 号橋梁の総延長は $381.80 \mathrm{~m} ゙, 39 \mathrm{~m}$ スパン 1 連， $77 \mathrm{~m}$ スパン 1 連，52mスパン 5 連の計 7 連の単 純トラスから構成されており，7連すべてが鋼製の 下路ワーレントラスである。さらに下路䘕の幅は $6.0 \mathrm{~m}$ トトラスの高さは $8.0 \mathrm{~m}$ である。これらのラス はリベット打ちで組み立てられ，約450七の鋼材が 使用された。また，設計荷重は森林鉄道一級線 （F.R.S.12）が適用され， $12 \mathrm{~kg}$ の軌条が $45 \mathrm{~cm}$ 間隔に 


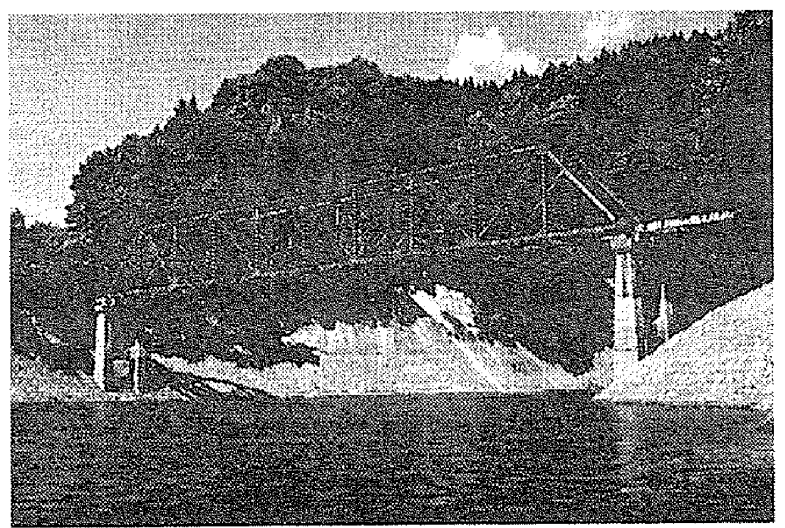

写真 2 夕張岳森林鉄道第 4 号橋梁（撮影：今 尚之）

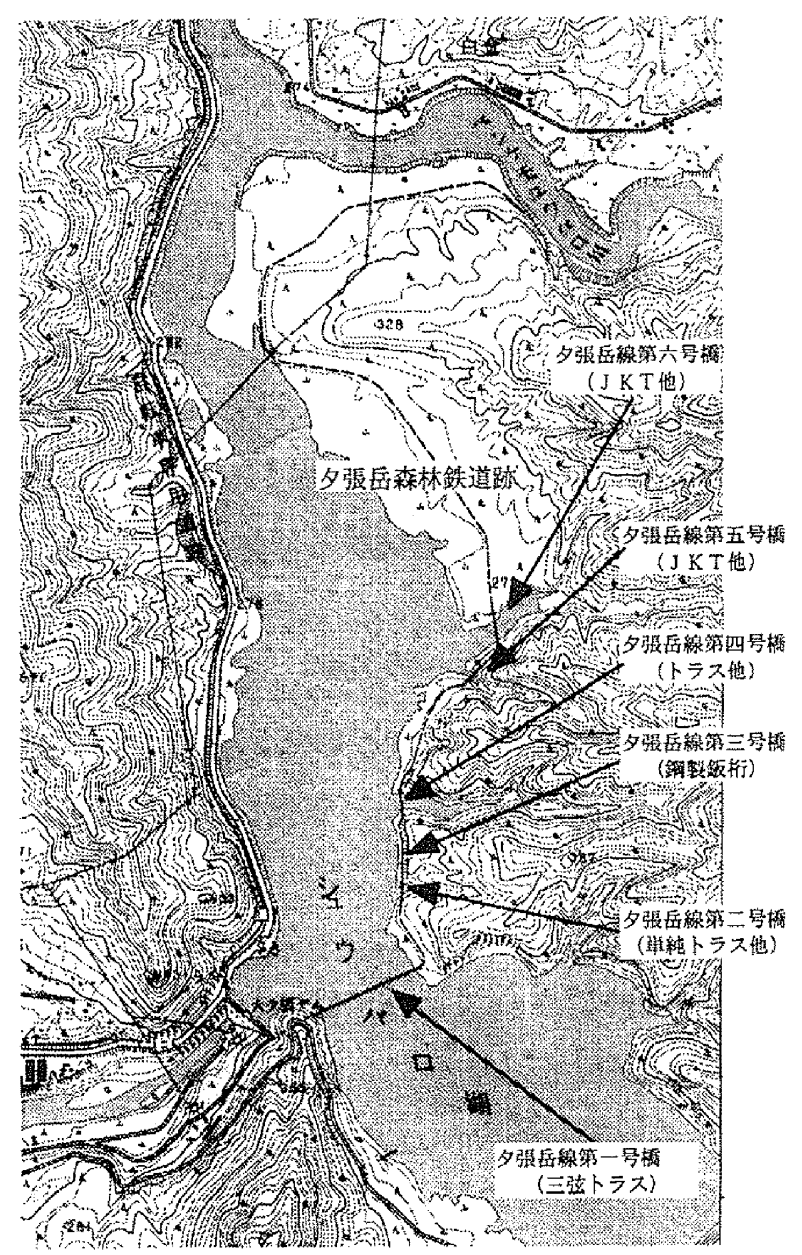

図 4 夕張岳森林鉄道におりる 大夕張ダム補償工事による橋梁

国土地理院2万 5 千分の一地形図・シニウパロ湖に加筆 (作成：今 尚之)

置かれた $18 \mathrm{~cm} \times 20 \mathrm{~cm} \times 200 \mathrm{~cm}$ の枕木の上に敷設され た。図 5 に52mスパントラスの正面図を示す。

また，橋台，橋脚は鉄筋コンクリート製である。 橋脚の形は $\pi$ 型，左右のピア間を横析で連結補強す

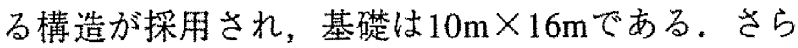
に，最も高い橋脚は $42.5 \mathrm{~m}$ の高さを持ち，ダム貯水 前における川面からの橋梁高は68mであった。な扔

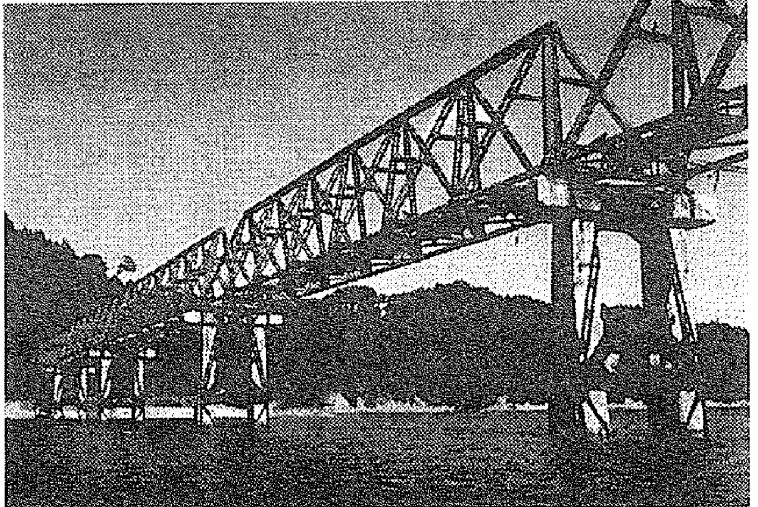

写真 3 夕張岳森林鉄道第 1 号橋梁（掫影: 今 尚之）

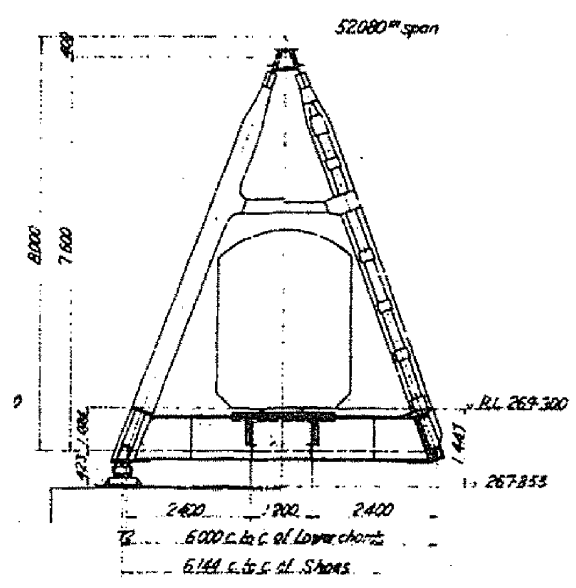

図 5 夕張岳森林鉄道第 1 号槁梁正面一般図 (52mスパン)

(東京鉄骨橋梁製作所：夕張岳線第 1 号橋梁 架設構造計算昰抒よび設計図面)

三弦橋の架設総工費は152,785,336冈で，下部構造は 大成建設が担当し，上部構造は東京鐡骨橋梁製作所 により架設された。

\section{(2) 三弦トラス構造の採用理由}

夕張岳森林鉄道第 1 号橋梁が三弦構造のトラスと いう極めてまれな構造を採用した理由は，（i）使用 鋼材量を滅らし，建設コストを下げることができ る。（ii）安定性の高い構造とすることができる。 （iii）周辺の景観を損ねない構造的意匠を持たせる ことができる，の三点である，当初夕張岳線の補償 工事はシューパロ湖の上流部に架橋し，橋梁延長を 短くする計画であった。しかし，迁回距離が長くな り営林事業に支障をきたすことから湖を直角に横断 する形に変更するよう営林側より要求が出され，第 1 号橋梁の橋梁延長が延びることとなった。この面 からもスパン長が長い場合，通常の四弦構造のトラ 
ス橋よりも使用鋼材量の面で有利となる三弦トラス 橋が採用されたと考えられる。さらに，水没補償工 事によって架設された鉄橋11橋のうち半数近くの 5 橋が転用架設であることからも，架設コストの低減 が徽底的になされたものと思われる。

安定性の向上であるが，ダム堰堤が近いため橋梁 高が非常に高くなる（68m）ので重心が低く安定性 が高い構造が望まれた。応力計算での必要断面積は 三弦でも四弦でも大差がないが，上弦材が1本であ る三弦の場合, 細部構造の重量が半減されることに なる、三弦橋の $77 \mathrm{~m}$ スパンにおける鋼重では，上弦 材とポータルの鋼重を合計した場合，三弦構造では $23.4 \mathrm{t}$ ，四弦構造では $40.4 \mathrm{t}$ と約 $1 / 2$ の鋼重となって いる。この結果重心が低くなり安定した構造物と なった。

周辺環境への配慮であるが, 夕張岳森林鉄道第 1 号橋梁は完成後シューパロ湖のランドマーク的存在 として地元で高い評価を受け，地元の観光スタンプ の図案にまで用いられている。関倸者へのヒアリン グによると「ダム湖であるシューパロ湖完成後, 借 景となる夕張岳の眺望を壊さず，周辺環境にとけ込 む構造」として選ばれたという。このように工事費 の節減と同時に周辺環境との調和を目指して構造様 式が決定されたことは，高い評価を与えることがで きよう。

(3) 夕張岳森林鉄道第 1 号橋梁と関係する技術者

この橋梁建設では, 当時北海道開発局建設部道路 課橋梁係長の有江義晴が橋梁構造の決定および基本 設計を，架設は株式会社東京鐵骨橋梁製作所が担当 し，当時東京鐵骨橋梁製作所に勤赤していた黒田幸 治を中心として設計，工場組み立て，現場架設が行 われた。

有江義晴は, 北海道大学工学部土木工学科にて, 鹰部屋福平教授に師事し，1936（昭和11）年に卒業 後, 横川橋梁を振り出しに, 常に第一線の技術者と して主として橋梁の架設に従事した。しっかりとし た構造計算を優先し，構造的な合理性による様式美 を好んだといわれ，北大時代に薫陶を受けた鷹部屋
福平に生涯師事しており，理論的な相談等をしてい たという。磚部屋は『まことの「橋のうつくしさ」 は単なる「かざり」，「装飾」だけで得られるもの ではない．均整のとれた「橋の美しさ」は，いずれ の部分をとって眺めてみても，それが力学上の理論 にしたがって計算から合理的に設計，無駄に遊んで いるところがないということが大切である。(中 略）必要なたけけ生きた材料が活躍しているのが力 強い美を示すのである。しかし，橋が単独に美しく てもそれは，片手落ちとなるものであって，周囲の 景色との調和，環境と比べての適合性が忘れてはな らない他の反面の重要さである(橋のいろいろ)』 と述べている。このことは，有江の構造物に対する 基本的な姿勢とも一致するものである，有江の技術 観は鷹部屋の影響と現場での架設経験で培われたも のといえよう。これらからも，三弦トラス構造を採 用した夕張岳森林鉄道第 1 号橋梁は有江と鷹部屋の 技術観を端的に表した構造物と考えられる。

\section{（3）重構桁鉄道橋}

\section{(1) 大夕張ダム補償工事と重構桁鉄道橋}

大夕張ダム補償工事では，重構桁鉄道橋が 2 橋架 橋された。補償工事上流部の夕張岳森林鉄道第 5 号，第 6 号橋梁が該当する.

第 5 号橋梁は全長 $37.65 \mathrm{~m}$ で，重構桁（20m× 1），鋼製版桁 $(6 \mathrm{~m} \times 1 ， 10.155 \mathrm{~m} \times 1)$ 加らな り, 重構桁部分が $20 \mathrm{~m}$ と短いために一重構造となっ ている，製造淥館ドックである，また，橋長から ダム水没前の夕張岳森林鉄道第 1 号橋の重構桁を転

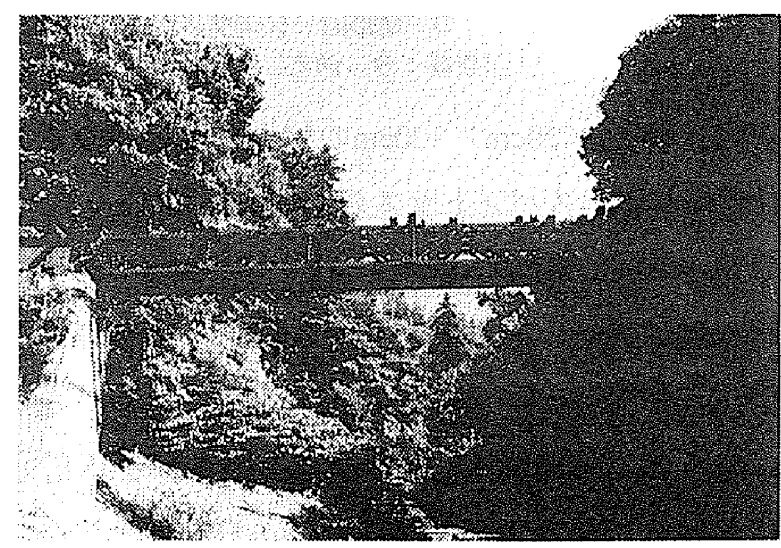

写真 4 夕張岳森林鉄道第 5 号橋梁（撮影：今 尚之） 


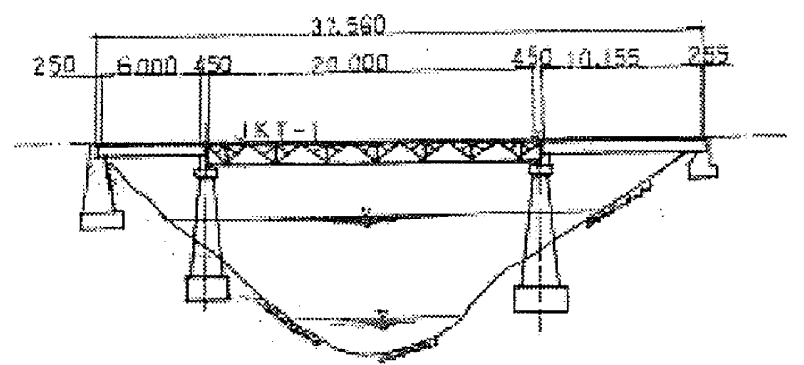

図 6 夕張岳森林鉄道第 5 号橋梁（作成：進藤義郎）

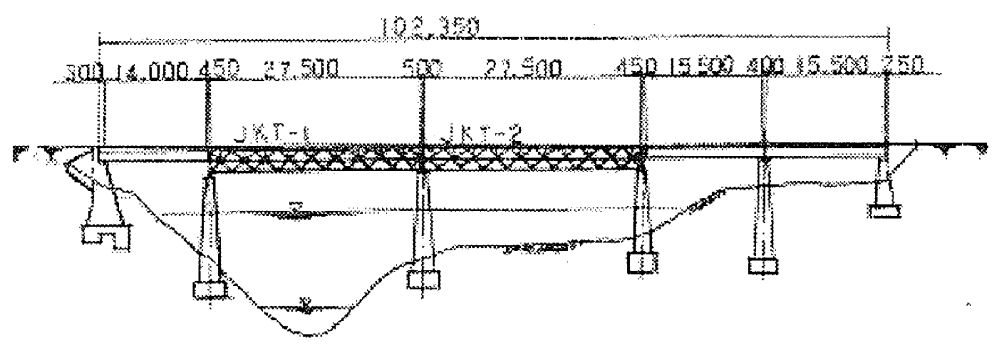

図 7 夕張岳森林鉄道第 6 号橋梁（作成：進藤義郎）

用したものではないかと推察される.

第 6 号橋は，全長 $102.35 \mathrm{~m}$ で重構桁 $(27.5 \mathrm{~m}) \times 2$, 鋼製版桁 $(14 \mathrm{~m} \times 1$ ， $15.5 \mathrm{~m} \times 2)$ からなる. 重構桁部分が $27.5 \mathrm{~m}$ と長いために二重構造となり強度 を增している．また，橋長からダム水 没前の夕張岳森林鉄道下夕張川橋梁の 転用と推察される.

なお，大夕張地区には重構桁鉄道橋は 以上 2 橋のほか小巻沢林道においても 架橋（全長 $45 \mathrm{~m}$ ，重構桁 $20 \mathrm{~m} \times 1$ ，鋼製 版桁 $8 \mathrm{~m} \times 2,9 \mathrm{~m} \times 1)$ されており，現在 3 橋の存在が確認されている.

(2) 重構桁鉄道橋の系譜 5 ?

重構桁鉄道橋は，旧日本陸軍の組立

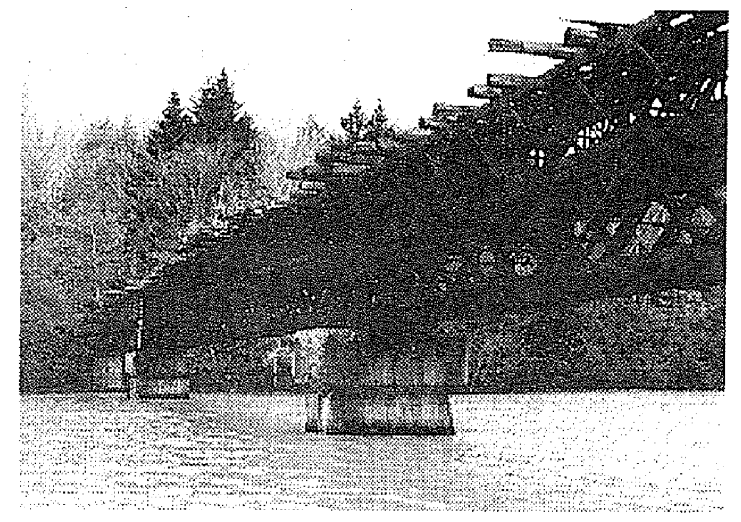

写真 5 夕張岳森林鉄道第 6 号橋梁（摄影: 今 尚之）

表 4 重構桁鉄道橋の特徴 （参考文献 5）より作成：今 尚之）

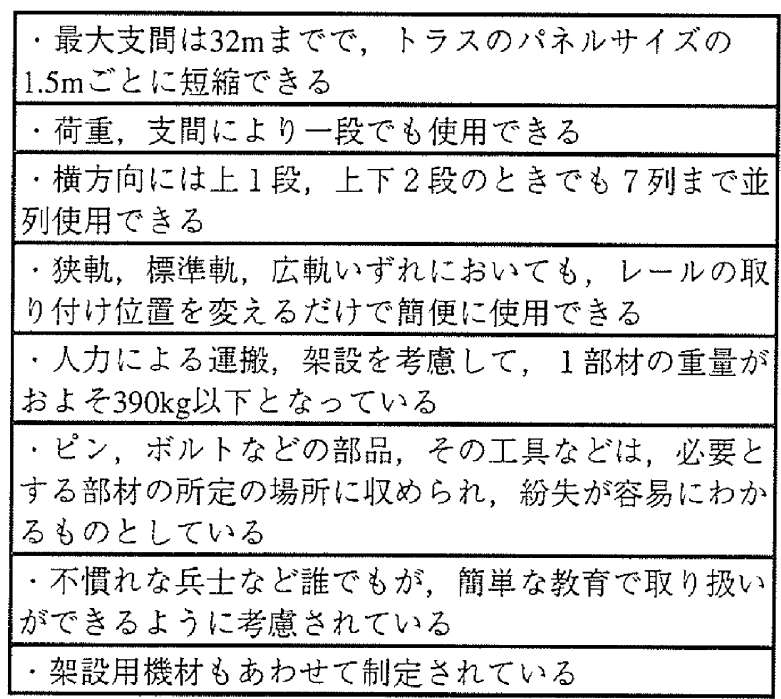
式トラス橋の総称であり, 戦地における応急架橋に 多用された，奈良一郎の論文”!によると「広軌，標 準軌および狭軌鉄道上を走る蒸気機関車に率引され た列車, 重荷重を通過させうる組立式トラス」とし て定義されている，奈良の研究によると，重構桁鉄 道橋は1929（昭和 4）年頃から試作・実験を行い, $\mathrm{J} K \mathrm{~K} \rightarrow$ 九十三式重構桁鉄道橋 $\rightarrow$ 九六式重構桁鉄

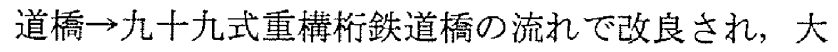
量に製作，使用され終戦を迎えている.

当時の記録などから判断すると夕張岳森林鉄道な どにおいて架橋されたものは，第3 次改良によって 制式化された九十九式重構桁の規格にもとづいて製 造されたものと推察される.

重構析鉄道橋は，ピンで結合させながら全溶接さ れた三角形のパネルを組み合し必要な橋長を得る単 純な構造でありながら必要な強度を得るメリットを 持つ. その特徴を表 4 に示す。

重構桁鉄道橋は日本における溶接鉄道橋の喨矢的 存在としても考えられ，また，戦地での仮設橋のみ ならず，戦後歩道橋や国鉄における流失橋梁の復旧 などにしばしば使われており，技術的な系譜や特徵 について，今後さらに研究を進める必要があるう。 


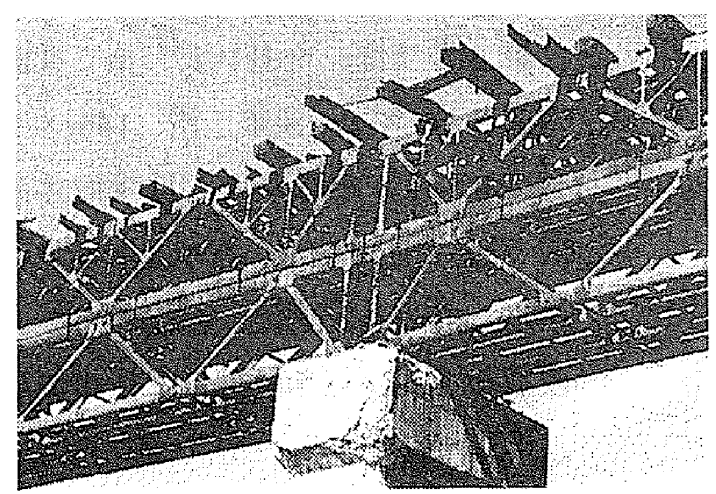

写真 6 夕張岳森林鉄道第 6 号橋梁のトラスパネル (撮影：今 尚之)

6. まとめ

本研究では, 夕張シューパロ湖周辺地域の森林鉄 道橋梁の建設過程や諸元を整理し，現地調査などに よってその残存状況を明らかにした。その結果以下 のことがわかった。

（1）戦後復興期に加北海道の基盤産業を支え てきた森林開発に供用された土木構造物が 集中して残存している。

（2）規模の小さいものや簡易な形態のものが多 いが，三弦トラス形式橋梁，重構桁鉄道橋 など特徽的な構造形式を採用した橋梁が現 存している。

（3）大夕張地区では木橋の落橋事故が多発し, このため鋼橋への置き換えが積極的に進め られ，重構桁鉄道橋など特異な構造様式の 橋梁が数多くかけられることとなった。

（4）夕張岳線第一号橋梁の架設ではコストの低 減と同時に周辺景観への影響もあわせて配 慮され，三弦トラス形式が採用された。

また, 今後の課題, 提案点として以下が指摘され よう.

（1）重構桁鉄道橋については，1955（昭和30） 年代においては仮穚などとして鉄道災害の 復旧などに多用されたが，現在残っている のは大夕張地区のみと考えられる。今後重 構桁鉄道橋の系譜や構造的特徴について,
橋梁技術史の観点からさらなる整理が必要 である。

（2）シューパロダムの建設で現在よりも湛水水 位が上昇することから，三弦トラ久橋梁や 重構桁鉄道橋梁は水没する。このため，撤 去対象となっているが，森林資源開発と石 炭資源開発で開発されてきた夕張，ひいて は北海道の歴史的モニュメントとして，保 存と活用が望まれる。

（3）活用に当たっては安易な方法に頼らず，地 域づくりと連携して，将来にわたり活用さ れるものとなることが重要である。

〈謝辞〉

本研究を進めるうえで，大変多くの方々のお力添 えをいたたいた，特に，釧路笠作所奥山道紀氏には 各種資料の提供をはじめ数多くの貴重なアドバイス をいただいた。さらに，東京鉄骨橋梁顧問奈良一郎 氏には重構桁鉄道橋梁に関する資料や蛽重な扔話し を頂戴した。また，クリエート工房西野昭平氏には 現地調查や写真撮影にご協力いただいた。ここに記 して謝辞と致します。

<参考文献 >

1) 進藤義郎, 今 尚之, 原口征人, 佐藤犚一：夕張 シューパロ湖周辺に扔ける穚梁土木遗産につい $\tau$, 土木学会北海道支部諭文報告集第 55 号 (B)，1999年

2) 竹中一雄: 木橋加ら鉄橋へ，札瀑林友第1号，林野 弘済会札幌支部，1954年

3）河野哲也, 今 尚之: 大夕張周辺に今も残る森林 鉄道用橋梁を訪视て, 虹橋58号, 社団法人日本橋 梁建設協会, 1998年

4）今 尚之, 原口征人, 佐藤馨一: シューパロ湖三 弦トラス橋の計画・設計思想に関する研究, 土木 学会北海道支部論文報告集第53号(B)，1997年

5）奈良一郎：幻の重構桁鉄道橋一日本最初の溶接鉄 道析一，東骨技報No.43，1997年 